\title{
Green Marketing In India: Emerging Opportunities And Challenges
}

\author{
Babita Saini \\ India, $D U$
}

\begin{abstract}
Environmental issues have gained importance in business as well as in public life throughout the world. As society becomes more concerned with the natural environment, businesses have begun to modify their behavior in an attempt to address society's "new" concerns. Some businesses have been quick to accept concepts like environmental management systems and waste minimization Eco-friendly products, and have integrated environmental issues into all organizational activities. Green marketing is a phenomenon which has developed particular important in the modern market and has emerged as an important concept in India as in other parts of the developing and developed world, and is seen as an important strategy of facilitating sustainable development. Green marketing is a tool used by many companies in various industries to follow this trend. The development of green marketing has opened the door of opportunity for companies to co-brand their products into separate line, lauding the green-friendliness of some while ignoring that of others. The paper identifies the three particular segments of green consumers and explores the challenges and opportunities businesses have with green marketing. The paper also examines the present trends of green marketing in India and describes the reason why companies are adopting it and future of green marketing and concludes that green marketing is something that will continuously grow in both practice and demand. It also focuses some of the problems with green marketing.

Key Words: Green marketing, sustainable development, Eco-friendly, Environmental issues.
\end{abstract}

\section{Introduction}

Development and conservation professionals are increasingly incorporating conservation products into their portfolio of activities to contribute to biodiversity conservation and poverty alleviation for the communities that live in high biodiversity areas. Tremendous progress has been made in involving communities in good conservation practices, developing enterprises that are sustainable and generating income that also promotes biodiversity conservation. GreenMarketing: refers to the process of selling products and/or services based on their environmental benefits. Such a product or service may be environmentally friendly in it or produced and/or packaged in an environmentally friendly way. "Green Marketing involves developing and promoting products and services that satisfy customers want and need for Quality, Performance, Affordable Pricing and Convenience without having a detrimental input on the environment.

\section{Literature Review}

The term green marketing came into prominence in the late 1980s and early 1990s. The first wave of green marketing occurred in the 1980s. The tangible milestone for the first wave of green marketing came in the form of published books, both of which were called greem marketing. They were by ken pattie (1992) in the United Kingdom and by Jacquelyn ottman (1993) in the United States of America. According to the American marketing association green marketing is the marketing of products that are presumed to be environmentally safe. Thus green marketing incorporates a broad range of activities, including product modification, changes to the production process, packaging changes, as well as modifying advertising. Yet defining green marketing is not a simple task where several meanings intersect and contradict each other; an example of this will be the existence of varying social, environmental and retail definitions attached to this term. Other similar terms used are Environmental Marketing and Ecological Marketing. Thus in a holistic approach the green marketing is defined as the concept where in the production, marketing of environmental safe product and services happened in a manner that is less detrimental to the environment with growing awareness about the implication of global warming and calamities which is going to happen due to environmental disturbance, non biodegradable solid waste, harmful impacts of pollution etc. both marketers and consumers are becoming increasingly sensitive. While the shift to green may appear to be expensive in the short term, it will definitely prove to be indispensable and advantageous cost - wise too, in the long run. Thus Green, environmental and eco marketing are part of the new marketing approaches which do not just refocus, adjust or enhance existing marketing thinking and practice, but seek to challenge those approaches and provide a substantially different perspective. In more detail green, environmental and eco-marketing belong to the group of approaches which seek to address the lack of fit 
between marketing as it is currently practiced and the ecological and social realities of the wider marketing environment

\section{Challenges in Green Marketing}

1) Need for standardization: It is found that only $5 \%$ of the marketing messages from "Green" campaigns are entirely true and there is a lack of standardization to authenticate these claims. There is no standardization currently in place to certify a product as organic. Unless some regulatory bodies are involved in providing the certifications there will not be any verifiable means. A standard quality control board needs to be in place for such labeling and licensing.

2) New concept: Indian literate and urban consumer is getting more aware about the merits of green products. But it is still a new concept for the masses. The consumer needs to be educated and made aware of the environmental threats. The new green movements needs to reach the masses and that will take a lot of time and effort. By India's ayurvedic heritage, Indian consumers do appreciate the importance of using natural and herbal beauty products. Indian consumer is exposed to healthy living lifestyles such as yoga and natural food consumption. In those aspects the consumer is already aware and will be inclined to accept the green products.

3) Patience and Perseverance: The investors and corporate need to view the environment as a major longterm investment opportunity, the marketers need to look at the long-term benefits from this new green movement. It will require a lot of patience and no immediate results. Since it is a new concept and idea, it will have its own acceptance period.

\section{Avoiding Green Myopia:}

The first rule of green marketing is focusing on customer benefits i.e. the primary reason why consumers buy certain products in the first place. Do this right, and motivate consumers to switch brands or even pay a premium for the greener alternative. It is not going to help if a product is developed which is absolutely green in various aspects but does not pass the customer satisfaction criteria. This will lead to green myopia. Also if the green products are priced very high then again it will loose its market acceptability.

Some Other Challenges Ahead In Green Marketing Are:

- Green products require renewable and recyclable material, which is costly

- Requires a technology, which requires huge investment in R \& D

- Water treatment technology, which is too costly

- Majority of the people are not aware of green products and their uses

- Majority of the consumers are not willing to pay a premium for green products.

\section{Green Washing}

In spite of its growing popularity, the green marketing movement faced serious setbacks in the late 1980s because many industries made false claims about their products and services. For instance, the environmental organization Corp Watch , which issues annually a list of the top ten"green washing" companies, included BP Amoco for advertising its "Plug in the Sun" program, in which the company installed solar panels in two hundred gas stations, while continuing to aggressively lobby to drill for oil in the Arctic National Wildlife Refuge. Green marketing can be a very powerful marketing strategy though when it's done right. In a similar kind of case Chad's green marketing campaign bombed because he made the mistake of packaging his environmentally friendly product in Styrofoam, emitting CFC's. Without environmental labeling standards, consumers could not tell which products and services were truly beneficial. Consumers ended up paying extra for misrepresented products. The media came up with the term "green washing" to describe cases where organizations misrepresented themselves as environmentally responsible. So, While green marketing was growing greatly as increasing numbers of consumers were willing to back their environmental consciousnesses

with their dollars, it can be dangerous. The public tends to be skeptical of green claims to begin with and companies can seriously damage their brands and their sales if a green claim is discovered to be false or contradicted by a company's other products or practices. Thus, in other words presenting a product or service as green when it's not is called green washing.

\section{The Green Dilemma}

The past decade has shown that harnessing consumer power to effect positive environmental change is far easier said than done. The so-called "green consumer" movements in the country have struggled to reach critical mass and to remain in the forefront of shoppers' minds. One of green marketing's challenges is the lack of standards or public consensus about what constitutes "green". This lack of consensus - by consumers, marketers, activists, regulators, and influential people -- has slowed the growth of green products, says Makeover, because companies are often reluctant to promote their green attributes, and consumers are often 
skeptical about claims. Despite these challenges, green marketing has continued to gain adherents, particularly in light of growing global concern about climate change. This concern has led more companies to advertise their commitment to reduce their climate impacts, and the effect this is having on their products and services.

\section{Golden rules of Green Marketing}

1) Know your customer: If you want to sell a greener product to consumers, you first need to make sure that the consumer is aware of and concerned about the issues that your product attempts to address.

2) Empower consumers: Make sure that consumers feel, by themselves or in connect with all the other users of your product, that they can make a difference. This is called "empowerment" and it's the main reason why consumers buy greener products.

3) Be transparent: Consumers must believe in the ligitimacy of your product and the specific claims you are making. The rest of your business policies are consistent with whatever you are doing that's environmentally friendly.

4) Reassure the buyer: Consumers must be made to believe that the product performs the job it's supposed to do-they won't forego product quality in the name of the environment.

5) Consider your pricing: If you are charging a premium for your product and many environmentally preferable products cost more due to economies of scale and use of higher-quality ingredients-make sure that consumer can afford the premium and feel it's worth it. Many consumers, of course, can't afford premiums for any type of product these days, much less greener ones, so keep this in mind as you develop your target audience and product specifications.

Green Marketing- Adopts by the firms

Green marketing has been widely adopted by the firms worldwide and the following are the possible reasons cited for this wide adoption:-

1) Opportunities: As demand changes, many firms see these changes as an opportunity to exploit and have a competitive advantage over firms marketing non-environmentally responsible alternatives. Some examples of firms who have strived to become more environmentally responsible in an attempt to better satisfy their consumer needs are :-McDonald's replaced its clam shell packaging with waxed paper because of increased consumer concern relating to polystyrene production and Ozone depletion.

The Surf Excel detergent which saves water(advertised with the message-"do bucket paani roz bachana").

- The energy-saving LG consumer's durables are examples of green marketing.

- We also have green buildings which are efficient in their use of energy, water and construction materials, and which reduce the impact on human health and the environment through better design, construction, operation, maintenance and waste disposal. In India, the green building movement, spearheaded by the Confederation of Indian industry (CII) -Godrej Green business

Center, has gained tremendous impetus over the last few years. From 20,000 sq ft in 2003, India's green building footprint is now over 25 million sq $\mathrm{ft}$.

- Xerox introduced a "high quality" recycled photocopier paper in an attempt to satisfy the demands of firms for less environmentally harmful products.

2) Government Pressure: As with all marketing related activities, governments want to "protect" consumer and society; this protection has significant green marketing implications. Government regulation relating to environmental marketing are designed to protect consumers in several ways, Reduce production of harmful goods or by-products modify consumer and industry's use and consumption of harmful goods .Ensure that all types of consumers have the ability to evaluate the environmental composition of goods. Governments establish regulations designed to control the amount of hazardous wastes produced by firms.New Delhi, the India's capital was getting polluted gradually at a very fast pace till Supreme Court of India forced a change of fuel on it. In 2002, a directive was issued to completely adopt CNG in all public transport systems to curb pollution. One of the more recent publicized environmental regulations undertaken by governments has been the establishment of guidelines designed to "control" green marketing claims. These regulations include the Australian Trade Practices Commission's (TPC) "Environmental Claims in Marketing - A Guideline, the US Federal TradeCommission's (FTC) "Guides for the Use of Environmental Marketing Claims" and the regulations suggested by the National Association of Attorneys- General .These regulations are all designed to ensure consumers have the appropriate information which would enable them to evaluate firm's environmental claims.4) 
Competitive Pressure: Another major force in the environmental marketing area has been firms' desire to maintain their competitive position. In many cases firms observe competitors promoting their environmental behaviors and attempt to emulate this behavior. In some instances this competitive pressure has caused an entire industry to modify and thus reduce its detrimental environmental behavior.

Social Responsibility: Many firms are beginning to realize that they are members of the wider community and therefore must behave in an environmentally responsible fashion. This translates into firms that believe they must achieve environmental objectives as well as profit related objectives. This results in environmental issues being integrated into the firm's corporate culture.

\section{SOME CASES}

Interestingly, green marketing continues to be an issue of $\mathbf{5}$ global interest. In fact, Google Trends reports that, on a relative basis, more searches for "green marketing" originated from India than from any other country.

$\begin{array}{ll}\text { Rank } & \text { Country } \\ \text { 1. } & \text { India } \\ \text { 2. } & \text { UK } \\ \text { 3. } & \text { US } \\ \text { 4. } & \text { Thailand } \\ \text { 5. } & \text { Australia } \\ \text { 6. } & \text { Canada } \\ \text { 7. } & \text { China }\end{array}$

Many companies are adopting green for capturing market opportunity of green marketing some cases

\section{EXAMPLE 1 : Best Green IT Project: State Bank of India: Green IT@SBI}

By using eco and power friendly equipment in its 10,000 new ATMs, the banking giant has not only saved power costs and earned carbon credits, but also set the right example for others to follow. SBI is also entered into green service known as "Green Channel Counter". SBI is providing many services like; paper less banking, no deposit slip, no withdrawal form, no checks, no money transactions form all these transaction are done through SBI shopping \& ATM cards. State Bank of India turns to wind energy to reduce emissions: The State Bank of India

became the first Indian bank to harness wind energy through a 15-megawatt wind farm developed by Suzlon Energy. The wind farm located in Coimbatore uses 10 Suzlon wind

turbines, each with a capacity of $1.5 \mathrm{MW}$. The wind farm is spread across three states - Tamil Nadu, with 4.5 MW of wind capacity; Maharashtra, with $9 \mathrm{MW}$; and Gujarat, with 1.5

MW. The wind project is the first step in the State Bank of India's green banking program dedicated to the reduction of its carbon footprint and promotion of energy efficient processes, especially among the bank's clients.

\section{EXAMPLE 2 : Lead Free Paints from Kansai Nerolac}

Kansai Nerolac Paints Ltd. has always been committed to the welfare of society and environment and as a responsible corporate has always taken initiatives in the areas of health, education, community development and environment preservation. Kansai Nerolac has worked on removing hazardous heavy metals from their paints. The hazardous heavy metals like lead, mercury, chromium, arsenic and antimony can have adverse effects on humans. Lead in paints especially poses danger to human health where it can cause damage to Central Nervous System, kidney and reproductive system. Children are more prone to lead poisoning leading to lower intelligence levels and memory loss.

\section{EXAMPLE 3 : Indian Oil's Green Agenda}

\section{Green Initiatives}

- Indian Oil is fully geared to meet the target of reaching EURO-III compliant fuels to all parts of the country by the year 2010; major cities will upgrade to Euro-IV compliant fuels by that time.

- Indian Oil has invested about Rs. 7,000 crore so far in green fuel projects at its refineries; ongoing projects account for a further Rs. 5,000 crore.

- Motor Spirit Quality Improvement Unit commissioned at Mathura Refinery; similar units are coming up at three more refineries.

- Diesel quality improvement facilities in place at all seven Indian Oil refineries, several more green fuel projects are under implementation or on the anvil.

- The R\&D Centre of Indian Oil is engaged in the formulations of eco-friendly biodegradable lube formulations.

- The Centre has been certified under ISO-14000:1996 for environment management systems. 
GREEN FUEL ALTERNATIVES

In the country's pursuit of alternative sources of energy,

Indian Oil is focusing on CNG (compressed natural gas), Auto gas (LPG), ethanol blended petrol, bio-diesel, and Hydrogen energy.

\section{EXAMPLE 4 : India's 1st Green Stadium}

The Thyagaraja Stadium stands tall in the quiet residential colony behind the Capital's famous INA Market. It was jointly dedicated by Union Sports Minister MS Gill and ChiefMinister Sheila Dikshit on Friday. Dikshit said that the stadium is going to be the first green stadium in India, which has taken a series of steps to ensure energy conservation and this stadium has been constructed as per the green building concept with eco-friendly materials.

\section{EXAMPLE 5: Eco-friendly Rickshaws before CWG}

Chief minister Shiela Dikshit launched on Tuesday a battery operated rickshaw, "E-rick", sponsored by a cellular services provider, to promote eco-friendly transportation in the city ahead of the Commonwealth Games.

\section{EXAMPLE 6 : Wipro Green It.}

Wipro can do for you in your quest for a sustainable tomorrow- reduce costs, reduce your carbon footprints and become more efficient - all while saving the environment.

\section{Wipro's Green Machines (In India Only)}

Wipro Infotech was India's first company to launch environment friendly computer peripherals. For the Indian market, Wipro has launched a new range of desktops and laptops called Wipro Greenware. These products are RoHS (Restriction of Hazardous Substances) compliant thusreducing e-waste in the environment.

\section{EXAMPLE 7 : Agartala to be India's first Green City}

Tripura Sunday announced plans to make all public and private vehicles in Agartala run on compressed natural gas (CNG) by 2013, thus making the capital "India's first greencity".Tripura Natural Gas Co Ltd (TNGCL), a joint venture of the Gas Authority of India Ltd (GAIL) and the Tripura and Assam governments, has undertaken a project to supply CNG to all private and government vehicles.CNG will also be available to those now using electricity, petrol and diesel to run various machineries. TNGCL chairman Pabitra Kar told reporters. He said:

"The company will soon provide PNG connections to 10,000 new domestic consumers in the city and outskirts. Agartala will be the first city in India within the next three years to become a green city.

\section{EXAMPLE 8 : Going Green: Tata's new mantra}

The ideal global benchmark though is 1.5 . Tata Motors is setting up an eco-friendly showroom using natural building material for its flooring and energy efficient lights. Tata

Motors said the project is at a preliminary stage. The Indian Hotels Company, which runs the Taj chain, is in the process of creating eco rooms which will have energy efficient mini bars, organic bed linen and napkins made from recycled paper. But there won't be any carpets since chemicals are used to clean those. And when it comes to illumination, the rooms will have CFLs or LEDs. About $5 \%$ of the total roomsat a Taj hotel would sport a chic eco-room design. One of the most interesting innovations has come in the form of a biogas-based power plant at Taj Green Cove in Kovalam, which uses the waste generated at the hotel to meet its cooking requirements. Another eco-friendly consumer product that is in the works is Indica EV, an electric car that will run on polymer lithium ion batteries. Tata Motors plans to introduce the Indica EV in select European markets this year.

\section{Reason for use of green marketing in organisation}

Man has limited resources on the earth, with which she/he must attempt to provide for the worlds' unlimited wants. Hence there is "freedom of choice", that individuals and organizations have the right to attempt to have their wants satisfied. As firms face limited natural resources, they must develop new or alternative ways of satisfying these unlimited wants. When looking through the literature there are several suggested reasons for firms increased use of Green Marketing. Five possible reasons are as follows:

1. Organizations perceive environmental marketing to be an opportunity that can be used to achieve its objectives. 
2. Organizations believe they have a moral obligation to be more socially responsible. Governmental bodies are forcing firms to become more responsible.

3. Competitors' environmental activities pressure firms to change their environmental marketing activities.

4. Governmental bodies are forcing firms to become more responsible.

5. Cost factors associated with waste disposal, or reductions in material usage forces firms to modify their behaviour.

\section{GREEN MARKETING: SWOT ANALYSIS}

As in formulation of green strategy, a firm may evolve it from a SWOT analysis Environmental Audit

\section{STRENGTHS:}

- Marketers get access to new markets and gain an advantage over competitors that are not focusing on"greenness.

- Marketers can charge a premium on products that are seen as more eco-responsible.

- Organizations that adopt green marketing are perceived to be more socially responsible.

- Green marketing builds brand equity and wins brand loyalty among customers E.g. research and development capabilities for clean processes and green products and human resources committed to environmental protection.

\section{WEAKNESS:}

- Most customers choose to satisfy their personal needs before caring for environment.

- Overemphasizing greenness rather than customer needs can prove devastating for a product.

- Many customers keep away from products labeled "Green" because they see such labeling as a marketing gimmick, and they may lose trust in an organization that suddenly claims to be green. E.g. products cannot be recycled, and hazardous wastes of a company.

\section{OPPORTUNITIES:}

- Marketing to segment which are becoming more environmentally aware and concerned. These consumers are demanding products that conform to these new attitudes.

Organizations perceive green marketing to be a competitive advantage, relative to the competitors. Firms, therefore, strive to improve upon their societal awareness. This complements the increase in consumers' socially conscious behavior and will therefore give them an advantage over competitors who do not ad dress these issues E.g. offering an environmental friendly product and saving resources, and relating them

\section{THREATS:}

- Uncertainty as to the environmental impact of present activities, including that is perceived to be less environmentally harmful.

- Uncertainty as to which green marketing activities are acceptable from a government perspective.

- The possibility of a backlash from consumers or government based on existing green marketing

claims, threat one and two above may cause backlash to arise .E.g. competitors gain market shares with green products and increased environmental regulations).

\section{Suggestions:}

Green marketing is still in its infancy and a lot of research is to be done on green marketing to fully exploreits potential. There are some suggestion that an organizations should implement for catering challenges of green marketing and successful exploitation of green marketing. Those are: Consumer needs to be made more aware about the merits of Green products. It is still a new concept for the masses. The consumer needs to be educated and made aware of the environmental threats. It should be made sure that the consumer is aware of and concerned about the issues that your product attempts to address. Green Marketing campaign and green advertising is good step toward it. Consumers must be motivated to switch brands or even pay a premium for the greener alternative. Make sure that consumer feel that they can make a difference. Make sure that consumer feel that they can make a difference. This is called "empowerment" and due to this main reason consumers will buy greener products. Further steps should be taken to control false promise and claim by the marketer to maintain legitimacy and trust worthiness of green products. Consumers must be made to believe that the product performs the job it's supposed to do-they won't forego product quality in the name of the environment.

For effective and efficient implementation of this concept of Green Marketing the factor that plays a major role is the Government. Unless the government creates specific and stringent laws and utilizes its authority to implement them the concept cannot be conceptualized. If the Consumer, the Organization and the Government work in unison towards the common goal of minimizing the detrimental environmental impact of their activities, 
then they can surely save this environment and make this world a better place to live in. Thus leading brands should recognize that consumer expectations have changed. It is not enough for a company to green its products; consumers expect the products at they purchase pocket friendly and also to help reduce the environmental impact in their own lives too. Today's consumers are becoming more and more conscious about the environment and are also becoming socially responsible. Therefore, more companies should become responsible to consumers' aspirations. Many companies want to have an early mover advantage as they have to eventually move towards becoming green. Green marketing is very low on the agenda of most businesses and therefore its still an underleveraged USP (Unique Selling Proposition). Therefore, effective green marketing targeted at the right audiencewill make a difference.

\section{Conclusion}

Now this is the right time to select "Green Marketing" globally. It will come with drastic change in the world of business if all nations will make strict roles because green marketing is essential to save world from pollution. From the business point of view because a clever marketer is one who not only convinces the consumer, but also involves the consumer in marketing his product. With the threat of global warming looming large, it is extremely important that green marketing becomes the norm rather than an exception. Recycling of paper, metals, plastics, etc., in a safe and environmentally harmless manner should become much more systematized and universal. It has to become the general norm to use energy-efficient lamps and other electrical goods.

Marketers also have the responsibility to make the consumers understand the need for and benefits of green products as compared to non-green ones. In green marketing, consumers are willing to pay more to maintain a cleaner and greener environment. Green marketing assumes even more importance and relevance in developing countries.

\section{References}

[1]. Www.google.com

[2]. J.A Ottman,. et al, "Avoiding Green Marketing Myopia", Environment, www.greenmarketing.net/stratergic.html

[3]. Pavan Mishra and payal sharma, green marketing in India: emerging opportunities and challenges. 